\title{
Rethinking the creative power of God
}

\begin{tabular}{|c|c|}
\hline $\begin{array}{l}\text { Author: } \\
\text { Jan Muis }\end{array}$ & \\
\hline $\begin{array}{l}\text { Affiliations: } \\
{ }^{1} \text { Department } \\
\text { Theological Be } \\
\text { Protestant Th } \\
\text { University, Am } \\
\text { The Netherlan }\end{array}$ & $\begin{array}{l}\text { fystematic } \\
\text { liefs, } \\
\text { eological } \\
\text { isterdam, } \\
\text { ds }\end{array}$ \\
\hline $\begin{array}{l}{ }^{2} \text { Department } \\
\text { Christian Ethic } \\
\text { Theology, Uni } \\
\text { Pretoria, Sout }\end{array}$ & $\begin{array}{l}\text { Jogmatics and } \\
\text { s, Faculty of } \\
\text { versity of } \\
\text { Africa }\end{array}$ \\
\hline $\begin{array}{l}\text { Project leader } \\
\text { Project numb }\end{array}$ & $\begin{array}{l}\text { : J.Buitendag } \\
\text { er: } 02402343\end{array}$ \\
\hline $\begin{array}{l}\text { Description: } \\
\text { Prof. Dr Muis } \\
\text { in the researc } \\
\text { 'Theology of } \\
\text { by Prof. Dr Joh } \\
\text { Department o } \\
\text { and Christian } \\
\text { of Theology, } \\
\text { Pretoria and D } \\
\text { Faculty of The } \\
\text { Muis is a rese } \\
\text { of Prof. Buiten }\end{array}$ & $\begin{array}{l}\text { s participating } \\
\text { n project, } \\
\text { lature', directed } \\
\text { lan Buitendag, } \\
\text { f Dogmatics } \\
\text { Ethics, Faculty } \\
\text { niversity of } \\
\text { ean of the } \\
\text { ology. Prof. } \\
\text { arch associate } \\
\text { dag. }\end{array}$ \\
\hline $\begin{array}{l}\text { Correspondin } \\
\text { Jan Muis, } \\
\text { jmuis@pthu.n }\end{array}$ & g author: \\
\hline $\begin{array}{l}\text { Dates: } \\
\text { Received: } 23 \\
\text { Accepted: } 10 \\
\text { Published: } 24\end{array}$ & $\begin{array}{l}\text { ug. } 2016 \\
\text { Nept. } 2016 \\
\text { Nov. } 2016\end{array}$ \\
\hline $\begin{array}{l}\text { How to cite th } \\
\text { Muis, J., 2016, } \\
\text { the creative p } \\
\text { HTS Teologies } \\
\text { Theological St } \\
\text { a3842. http:// } \\
\text { org/10.4102/ }\end{array}$ & $\begin{array}{l}\text { is article: } \\
\text { 'Rethinking } \\
\text { ower of God', } \\
\text { Studies/ } \\
\text { udies 72(4), } \\
\text { dx.doi. } \\
\text { ts.v72i4.3842 }\end{array}$ \\
\hline $\begin{array}{l}\text { Copyright: } \\
\text { (C) 2016. The A } \\
\text { Licensee: AOS } \\
\text { is licensed un } \\
\text { Creative Comr } \\
\text { Attribution Lic }\end{array}$ & $\begin{array}{l}\text { uthors. } \\
\text { IS. This work } \\
\text { ler the } \\
\text { nons } \\
\text { ense. }\end{array}$ \\
\hline Read online: & \\
\hline 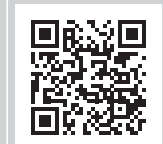 & $\begin{array}{l}\text { Scan this QR } \\
\text { code with your } \\
\text { smart phone or } \\
\text { mobile device } \\
\text { to read online. }\end{array}$ \\
\hline
\end{tabular}

Because the notion of 'power', and of 'absolute power' in particular, is associated with coercion, violence and oppression, it is problematic to attribute power to God. Jürgen Moltmann and Eberhard Jüngel reject a 'theistic', 'metaphysical' concept of God's 'absolute power' and highlight the powerlessness of the suffering and dying God on the cross. In their view, limitation of power is also central to God's creative power. In this article, this kenotic view on God's creative power is examined. Firstly, the political philosophy of Thomas Hobbes is explored as an important and still influential source of the modern view on absolute power as dominion. Next, it is discussed whether the innovative view on divine, creative power of Sören Kierkegaard can be seen as kenotic. Because both Hobbes and Kierkegaard refer indirectly to the classical distinction between potentia absoluta and potentia ordinata, this distinction, and its rejection by Schleiermacher, is investigated. The article concludes by proposing 'empowering power' as a non-oppressive and non-kenotic view on God's creative power.

\section{Is power compatible with God?}

It has become problematic to attribute power to God because power is generally seen as something fundamentally wrong: dominion, coercion, violence and oppression. In this perspective, to exercise power is nothing else than oppressing other people, violating their rights and destroying their lives and liberties. As Lord Acton said, 'Power corrupts, and absolute power corrupts absolutely.' Absolute power is the privilege of the tyrant. In political and economic situations where some powerful make thousands of powerless suffer and die, it is very hard to imagine a powerful God. This would easily suggest that God is on the side of the oppressors, and, even worse, that he himself is a tyrant, who destroys arbitrarily the freedom and life of others. A good, loving and just God cannot be on the side of the powerful that do wrong and bring injustice, $\mathrm{He}$ can only be on the side of those who suffer. God is not against; he is with the powerless. This is often construed in a radical manner: God identifies himself with the powerless; he is one of them. Taking this identification seriously implies that God himself is in a fundamental sense powerless. Many modern and postmodern theologians have replaced the traditional picture of a powerful God by the picture of a powerless and in some sense 'weak' God.

\section{The kenotic view on God's power}

An influential alternative for what they call a 'theistic' or 'metaphysical' understanding of God's power (Moltmann [1973] 2001:220-221; Jüngel [1986] 1990:154) has been proposed by Jürgen Moltmann and Eberhard Jüngel. They grounded their accounts of God's power on Luther's theology of the cross: in Jesus' suffering and death on the cross, God himself has suffered and died. In Jesus Christ, God has identified himself with suffering, dying, powerless people and has become one of them. In the centre of human history the incarnated God himself has become a victim of coercion, violence and oppression. The cross reveals the way God deals with power: God does not exercise power over and against other people, but allows other people to exercise their power against him. This is the way of love. God's love is not powerless; but the power of God's love is radically opposed to the coercive and oppressive power of the world; it is exercised precisely by renouncing coercion and violence. This renunciation can be seen as a form of 'kenosis'. Therefore, in this article, with Katherine Sonderegger (2015:154-164), I shall call the view of Moltmann and Jüngel and their followers (e.g. Welker 2013:189) the kenotic view on God's power.

Moltmann and Jüngel consider this kenotic power as God's only power in the world. They try to understand God's act of creation, traditionally conceived as a mighty act, as a form of kenosis. They take creation as God's original act by which other beings began to exist, to live and to act (Moltmann [1985] 1993:78-79; Jüngel [1986] 1990:151). They claim that the act of creation can only be understood as an act of self-limitation. Moltmann argues that God can only create a world 'outside' himself if he first makes room for it, that is, if he limits himself and restricts his power 
(Moltmann [1985] 1993:86-87). Jüngel argues that, to create something, implies to be limited by what you create. (Jüngel [1986] 1990:153-154). God's creative power is his power to give existence, life and agency to other beings. In Moltmann's and Jüngel's kenotic construal of God's creative power, God limits his own power by giving other beings the power to live and to act. Both Moltmann and Jüngel further clarify God's self-limitation in the act of creation by the Kabbalistic thought of 'zimzum', the contraction of God that makes space for something other than himself (Moltmann [1985] 1993:87; Jüngel [1986] 1990:157).

This kenotic construal of the act of creation as self-limitation presupposes that God's creative power to give existence and life to other beings and the created power to exist and to live are homogeneous: created power can only limit or restrict the power of God if it is the same kind of power. If creative power and created power are homogeneous, their difference is not qualitative, but quantitative: a matter of more or less. The more power God has, the less power creatures have, and the more power creatures have, the less power God has. In this view on power, you cannot give power to others without losing power yourself. And the other way round: you cannot acquire power without taking it from someone else. If one assumes that it is the same amount of power that is acquired by one party and lost by the other, one subscribes to the socalled zero sum explanation of power. 'This explanation hinges on alleged analogies between power and money, or power and the physical concept of energy. Basically, it amounts to the assumption that, if I gain a certain amount of power, necessarily one or more other people thereby lose an equal amount of power, so that the sum total of power remains the same' (Van den Brink 1993:122; cf. Muis 2016:321-322). As far as I know, Moltmann and Jüngel nowhere explicitly state that the same amount of power that God in his act of creation gives to his creatures is lost by him, but their arguments suggest a zero sum conception of divine and created power and definitely do not exclude such a view.

The kenotic view of divine power offers an alternative for the current view on power as oppressive and violent dominion over others which is not applicable to God, who is on the side of the sufferers from evil and the victims of oppression. But are these two modern conceptions of (divine) power, the oppressive view on power as absolute dominion and the kenotic view the only possible accounts of divine power? In order to explore this question, I want first to look at one important origin of the modern view on absolute power as dominion in the political philosophy of Thomas Hobbes (1588-1679). Next, I want to investigate the view on divine power of Sören Kierkegaard (1813-1855), because his explanation of the act of creation seems to suggest a kenotic view on divine power. Hobbes and Kierkegaard refer in different ways to the classical distinction between potentia absoluta and potentia ordinata. Therefore, I will consider this distinction and its rejection by Schleiermacher (1768-1834) more closely. I will conclude by proposing a non-kenotic and non-oppressive view on God's creative power as empowering power, following a lead of Wolf Krötke.

\section{Absolute power according to Thomas Hobbes}

In the genealogy of the modern concept of power, Thomas Hobbes is a key figure and his political philosophy is a turning point. Hobbes is well known for his view on the state, which he calls 'Leviathan'. According to Hobbes, by nature, all people had a right to everything (jus omnium in omnia) and all people had the power to live and to take the life of others. Therefore, the only way to avoid a war of all against all is that people give their rights and powers to the state (Hobbes 1561:xiv.4-8; xvii; xxxi.5). This contract is the foundation of the absolute state. Only an absolute state with absolute power can guarantee the right of its citizens to preserve their own lives and protect them against the power and violence of other citizens. The state is represented by the king. As a representative of the state the king has absolute power (Hobbes 1561:xx.16, with reference to 1 Samuel 8:11-17). Absolute power is unlimited power; to limit someone else's power is to make it less (Hobbes 1561:xx.18). This notion of absolute power is central to Hobbes's political philosophy.

Hobbes's view on absolute power marks the passage to early modernity and is very controversial. Some consider his absolutism as totalitarianism. The political philosopher Carl Schmitt, who supported the Nazis, appealed to Hobbes for his doctrine of the totalitarian state (see Steinvorth 2005). Others think Hobbes is the founder of individualistic liberalism (Cavanaugh 2011:20; Dupré 1993:139-143). The reason for these divergent interpretations is Hobbes's polysemic use of the term 'power' (Foisneau 2016:68-93).

My attention was drawn to Hobbes by a fascinating study of the French political philosopher and Hobbes specialist, Luc Foisneau, Hobbes et la toute-puissance de Dieu. Surprisingly, a notion of divine power appears to be fundamental to Hobbes' political philosophy. For Hobbes, omnipotence is the central attribute of God from which all his other attributes can be derived (Foisneau 2016:87-92). I will mention two elements of his concept of divine power that are important for the purpose of this article. Firstly, as to God's power in nature, Hobbes does not identify the power of God with the power of nature, as his contemporary Baruch de Spinoza (16321677) does (Foisneau 2000:207-213), but he too links the power of God very closely with nature, which he understands with Galilei as a closed system of natural causes (Foisneau 2000:47). For Hobbes, nature is not grounded in God's free will, but only in his omnipotence (Foisneau 2000:13-15). In nature, power means effective cause (Foisneau 2016:73-75), and everything happens necessarily (Foisneau 2000:9, 31-33). God is the first power of all powers, the first cause of all causes (Foisneau 2016:90). Secondly, with regard to God's power in relation to human beings, Hobbes underlines the difference between the power of God and the power of human beings (Foisneau 2000:14, $143,232)$. God has absolute power in the sense that he is the absolute sovereign over mankind; his sovereignty is grounded in his irresistible power (Hobbes 1651:xxxi.5; 
Foisneau 2000:14, 142). The crucial difference between the power of God and the power of human beings is that God can kill men, but that man cannot kill God (Foisneau 2000:233-234). This is very revealing. The ultimate power is the power to take someone else's life. For Hobbes, divine and human power are opposing powers. The absolute power of God can only limit the power of human beings, but it cannot be limited by human powers, because it is irresistible (Hobbes 1561:xxi.5).

That Hobbes's concept of power is indeed a turning point in the passage to modernity becomes clear when we compare it with the traditional distinction between potentia absoluta and potentia ordinata and with the account of God's omnipotence in the Glaubenslehre of Friedrich Daniel Schleiermacher. In the classical theological tradition, the existence of this world is understood as the result of the will of God and this will is understood as a free choice. God has created this world, but he could have done otherwise. In order to explain this freedom of God, the power he manifests in this world is distinguished from his power in himself and his power to create this world. His power in this world is bound by the order of the world he has created; his power to create this world is not. Gods power in the world is called potentia ordinata, and his power to create the world is called potentia absoluta (see Van den Brink 1993:68-92; Van der Kooi 2002:167-173). The notion of potentia ordinata implies that, by creating this world, God has limited the number of his possible actions; God can now only act in relation to the world as it is. In the course of history, God further freely limits his possible actions by making promises and covenants with people. Hobbes rejects the notion of God's potentia ordinata and any notion of limitation of his omnipotence by creation, promise and covenant (Foisneau 2000:44-48). It is instructive to compare Hobbes also with Schleiermacher, for whom God's omnipotence means that the causal nexus of nature is grounded in God and that everything that happens is caused by God (Schleiermacher [1821] 1960: §54; cf. Osthövener 1996:44-48; Sonderegger 2015:180-185). To be omnipotent is to be the cause of all that actually happens. Like Hobbes, Schleiermacher restricts omnipotence to effective causality in the actual reality of this world. God's omnipotence is his actual omnicausality and nothing more. For Schleiermacher it makes no sense to distinguish between God's power to do the possible and God's power to do the real. This is very similar to Hobbes indeed. All God's power is ordained, but this ordained power is understood as 'absolute', as irresistible causality.

\section{Kierkegaard's enigmatic remarks on divine power}

In his diaries, Kierkegaard writes some brief intriguing remarks on God's omnipotence that are very different from Hobbes' view. For Kierkegaard, the almighty God is the God who has become human in Jesus Christ. But the incarnation is for him no reason to replace God's omnipotence by his impotence. The incarnated God remains the almighty God.
Kierkegaard's response to the objection that God's omnipotence excludes human freedom is intriguing. He completely turns upside down the current view on the relation between divine power and human freedom. He claims that only God's power can make people free. How is this possible? Kierkegaard argues that omnipotence includes the capacity to make someone else independent. He makes some powerful statements on this point (Kierkegaard [1846] 2011):

The absolutely greatest thing that can be done for a being, greater than anything one could make it into, is to make it free. It is precisely here that omnipotence is required. (...) (Omnipotence) must precisely also contain the ability, in an expression of omnipotence, to retreat into itself again in such a way as to allow that which owes its existence to omnipotence to be independent. (...)

All finite power creates dependence, only omnipotence can create independence, creating from noting something that has its being in itself, while omnipotence continually retreats into itself. (...)

Only a wretched and worldly notion of the dialectic of power holds that power is greater and greater in proportion to its capacity to compel and to create dependence. No, Socrates understood it better: the art of power consists precisely in the capacity to make free. (...)

Creation out of nothing is, once again, an expression of the capacity of omnipotence to make someone independent. (...)

If in creating a human being, God himself had lost a little of his power, he would indeed be unable to make a human being independent. (pp. 56-57)

Vos and Moltmann construe this account of God's power as kenotic because Kierkegaard talks about the 'retreat into itself' of God's omnipotence (Vos 2002:110; Moltmann 2014:54). But this interpretation is implausible because Kierkegaard emphatically claims that omnipotence 'can give without giving up the least bit of its power' (Kierkegaard [1846] 2011, 57). According to Bauke-Ruegg, Kierkegaard understands God's relation to the world as a relation to himself, which implies that the world is a mode of being ('Daseinsweise') of God himself (Bauke-Ruegg 1998:177). In this interpretation, the difference between Creator and creation is abolished and the opposition between God's power and human power disappears. However, Kierkegaard stresses this opposition: 'All finite power creates dependence, only omnipotence can create independence (...)' (Kierkegaard [1846] 2011, 57).

Apparently, Kierkegaard's complex text contains a number of different arguments. How these different arguments relate to each other is not clear at first sight. Obviously, Kierkegaard tries to show that only infinite power can make a human being free. If I understand him correctly, he offers at least the following three reasons for this claim. The first reason is that it requires a greater power to make someone else free than to compel someone else. The second reason is that a human being can never make another human being completely free. A human being who exercises power to make another free, can himself not be free from exercising power over the other, 
which means that the other remains dependent on him. In addition, a human being cannot make someone else free without loving himself in doing this. The third reason is that only a being that has been created from nothing can be completely free.

On these three grounds Kierkegaard claims that infinite power is required to make a human being truly free. According to him, God has this power. God can create out of noting and he can retreat into himself, so that the being that has been created from noting becomes independent. The power to give oneself to another in such a way that the other becomes independent is goodness. Therefore, God's goodness is the power that makes human beings free. This means that God's creative omnipotence is 'empowering power' (Bauke-Ruegg 1998:177).

The most striking feature in Kierkegaard's account is the thought that God's omnipotence 'can retreat into itself', or 'can take itself back'. Compared with classical theology such terms are new. How should we understand them in the context of Kierkegaard's argument? Is this retreat a form of kenosis, of renouncing power, of making oneself powerless? Can it be compared with the notion of 'zimzum' in Kabbalistic literature, a contraction of God by which creation becomes possible? I think the answer to both questions is 'no'.

Kierkegaard talks about the retreat into itself of God's omnipotence in order to distinguish God's power from the power of human beings. When a human being uses power to liberate another human being, the relation between the liberator and the liberated remains marked by power. Therefore, human liberating power results inevitably in some kind of dependency of the liberated. With the notion of 'retreat into itself' or 'taking itself back' Kierkegaard expresses that God's power to liberate people is different: it does not make them dependent. 'This is what is inconceivable: Not only is omnipotence capable of producing the most impressive thing of all, the totality of the visible world, but is also capable of producing the most fragile thing of all, a being that is independent vis-à-vis omnipotence' (Kierkegaard [1846] 2011, 57). God's power to create people is not a renunciation of power, but the manifestation of divine, infinite power. Kierkegaard's view on God's power is not kenotic.

As to the notion of 'zimzum', Kierkegaard presents the thought of retreat and taking back neither as an alternative for the classical creatio ex nihilo, nor as an explanation for 'nothing' and the possibility of creatio ex nihilo, as Moltmann and Jüngel do. He talks about retreat besides the creatio ex nihilo. To put it another way: the creatio ex nihilo is depicted as both a manifestation and a retreat of God's omnipotence. Both the capacity to produce and the capacity to retreat belong to God's infinite power. Kierkegaard uses the notion of retreat in order to emphasise how a human being can be truly free and independent, not in order to explain how a human being comes into existence. Therefore we should not identify his concept of retreat with the Kabbalistic 'zimzum', the contraction that enables God to create the world.
Crucial to Kierkegaard's argument is the claim that the power to liberate someone else is greater than the power to compel someone else. He appeals for this to Socrates, but argues against Socrates that human beings cannot be liberated by the finite power of other human beings, but only by the 'greater', infinite power of God. Now, the question is how Kierkegaard understands 'greater power'? Is greater power more power, or is it another kind of power? In other words, is there a quantitative or a qualitative difference between divine and human power? Kierkegaard rejects the view that power is 'greater in proportion to the capacity to compel'. In this context, 'greater' can be understood quantitatively. But Kierkegaard thinks this is a false view. God's power to liberate human beings is greater than the human power to compel other human beings in another way. Because of the contrast between the divine power to liberate and the human power to compel, it is obvious that the difference between divine and human power is not quantitative, but qualitative (Vos 2002:109). God's power to create and to give a free and independent existence is another kind of power than the human power to compel.

Maybe, we can understand this 'greater' also as 'better'. Because freedom is a greater good than dependence, the power to liberate is a greater, better power than the power to compel someone else. This interpretation nicely fits in Kierkegaard's reasoning. If this interpretation is correct, Kierkegaard offers us a modern version of a type of argument that is characteristic for the Anselmian tradition of perfect being theology. The principle of this way of thinking is that we should ascribe to God those properties you can better have than not have, that is, perfectiones. Thomas Aquinas, for instance, argues that the power to create beings that can operate themselves is greater and more perfect that the power to create beings that cannot operate themselves (Van Aquino 1265:III.69.15; Van Aquino 1273:Ia.105.5). According to Thomas, this self-operating of human beings implies freedom, but not independence. In contrast with Kierkegaard, who identifies the two, Aquinas clearly distinguishes freedom from independence. In this respect, Kierkegaard's account is modern. We could characterise Kierkegaard's view on divine power as a modern form of perfect being theology: the power to create free, independent people is a greater, that is, more perfect power than the power to create dependent people. The creative power that can manifest and retreat omnipotence is a greater, a more perfect power, than the power that can only manifest but not retreat omnipotence.

\section{The modern rejection of the absoluta ordinata distinction}

The kenotic view on divine power is presented as an alternative for the absolute power of God, understood as unrestricted dominion, coercion and oppression: 'As the Almighty one who limits himself, God is the opposite (gospel) and therefore the criticism (judgment) of an unlimited will to power, which is realised in the form of brutal exercising power or becomes conscious in the form of desperate resignation to its limits (...)' (Jüngel, E., [1999] 
2003:269; translation JM). The picture of an 'unlimited, brutally exercised will to power' is described by Jüngel as 'metaphysical'. Jüngel seems to think that metaphysical power is despotic because it is absolute. However, the question is whether the understanding of God's power in classical theology is an instance of the 'metaphysical', 'absolute', despotic power Jüngel rejects. For two reasons this is doubtful. Firstly, as we have seen, in the classical tradition, God's power in this world in relation to human beings is understood as potentia ordinata and different from God's potentia absoluta to create from nothing. God's ordained power is relational. Secondly, God's ordained power implies certain limitations. By creating this world, by making promises to and covenants with people, God limits the number of his possible actions. His exercise of power in relation to the world is not absolute in the sense that it is without restraint and restrictions.

In fact, the understanding of God's absolute power as unrestricted and coercive dominion over and against men is typically modern. It emerges when the traditional distinction between potentia absoluta and potentia ordinata is abolished, God's power is restricted to his power in this world, his power in nature is interpreted as efficient all-causality and his power in relation to human beings is understood as irresistible dominion. It is the modern concept of power that excludes any form of restraint in God's exercise of power. This becomes particularly clear in Schleiermacher's discussion of the distinction between potentia absoluta, the power to do the possible, and potentia ordinata, the power to do the real. He rejects this distinction because it would imply the 'self-limitation' of God's omnipotence! Schleiermacher argues that, if God would have the power to do what is possible, his exercise of power in the reality of this world would be a diminishment of his power. When God's power is diminished, it is no longer omnipotence (Schleiermacher [1821] 1960: $\S 54.2^{c}$ ). In my opinion, this argument is not convincing. If someone performs an action, the number of his possible actions is diminished. But if this would mean that thereby his power has been diminished, someone who never acts would be more powerful than someone who acts. This is absurd. If God creates beings with whom he can establish a covenantal relationship, this may limit his logical possibilities to act, but it enlarges his real possibilities to have reciprocal relationships with other beings (cf. Muis 2016:323-324).

The fact that God has created human beings and given them the power to live and to act freely, does not imply any loss of his power. This would only be the case if God's creative power and the created power of human beings were homogeneous and the difference between them was merely quantitative. At this crucial point, Kierkegaard has shown a better way to understand the relation between creative and created power: the difference between divine and created power is not quantitative, but qualitative. Therefore the zero sum does not apply to the powers of God and of human beings. God loses none of his divine power by creating human beings and by giving them human power.
The current, modern rejection of any distinction between potentia absoluta and potentia ordinata has two far-reaching consequences. Firstly, if no distinction can be made between God's power in relation to the possible and his power in relation to the real, it becomes very difficult to understand creation as a free, personal act (Muis 2016:330-331). More generally, God's manifestation and revelation of power in relation to the world can only be understood as free if it is distinguished from his power 'in himself'. That God acts freely implies that his omnipotence is not exhausted by all he does (Barth 1942:592-594; Barth 1958:526-528). But is it not dangerous to distinguish between God in himself and God for us? The current argument against such a distinction between God's absolute and ordained power is that it postulates a hidden and totally different God behind the relational God who communicates with his creatures, a God who can arbitrarily exercise power and is therefore untrustworthy; therefore, all God's power is ordained and this ordained power is understood as relational (e.g. Krötke 2001:203-205). It is true that the distinction has been abused in this way in late medieval nominalism. But the abuse of this distinction does not negate its proper use. If we employ this distinction only to maintain and explain the freedom of God's creative power, no opposition or contradiction between God in his absolute power and in his ordained power is involved.

Secondly, if Gods power is restricted to what he operates in the world, it becomes difficult to distinguish divine power from created power. At this point, the example of Schleiermacher is instructive. His rejection of the distinction between potentia absoluta and potentia ordinata is closely related to his understanding of omnipotence as all-causality. But if we reduce God's power to his power in the world, and his power in the world to causality, God's power becomes a sort of magnified natural power. Barth has rightly argued that the abandonment of the distinction between what God can do and what God does do easily leads to the identification of the power of God with worldly power (Barth 1942:597; 1958:531). In his view, this identification is 'a blind deification of nature or history or fate, and finally of man himself' (Barth wrote this in 1942:598; 1958:531). Although Barth does not state his view in these terms, I think it is fair to say that he considers the difference between God's power and created power as a qualitative difference, and that he rejects Schleiermacher's view because it reduces this difference to a quantitative difference. In his own terms, Barth tried to express that God's power is a different kind of power than the power in the world (cf. Shults 2005:26, 30, 261).

\section{God's empowering power}

Because God's power is qualitatively different from created power, God can give power to human beings without losing anything of his own power. We can call this power to give power to human beings without losing anything of his own power, God's 'empowering power'. I take this expression from Wolf Krötke (2001:221; cf. Muis 2016:325). In his rich and stimulating book Gottes Klarheiten, Krötke interprets God's 
attributes on the basis of the life, death, resurrection, and presence in the spirit of Jesus Christ, in which God reveals himself. Krötke calls God's attributes 'clarities' because they radiate from God's glory and clarify and transform the existence of human beings. Two things are characteristic of the power God shows and exercises in Jesus Christ by his spirit. Firstly, God gives power to Jesus, and Jesus gives, in the power of the spirit, power to people in order that they live in love and peace with God and with each other. This empowering power of God can be seen in the authority of Jesus, his healings, his resurrection from the death, and in the power Christians receive from his spirit (Krötke 2001:215, $221,222,224,232)$. Second, in relation to human beings, God exercises his power not in a coercive and violent way, but in a careful way (Krötke 2001:220 223, 228). God's prudence is essential for his empowering power (Krötke 2001:220).

Can God's creative power be understood as empowering power? Krötke himself does not use the expression 'empowering power' to describe God's creative power, but his account does not exclude this use. In fact, it offers two important building blocks for it. Firstly, Krötke understands God's creation of human beings as an act of love and prudence. God gives human beings a free life, wants to love them as free persons and wants to be loved by them in freedom. This excludes coercion and violence. At the same time, Krötke rejects Moltmann's and Jüngel's kenotic explanation of the act of creation as self-limitation and as contraction, 'zimzum' (Krötke 2001:267). His rejection of coercive and violent power in God does not compel him to accept a kenotic view on God's creative power. Secondly, Krötke criticises Schleiermacher's identification of omnipotence and omnicausality (Krötke 2001:206-208). Moreover, he argues that the praise of God as creator implies the acknowledgement of his omnipotence, which includes God's creative possibilities (Krötke 2001:270). So, although he rejects the distinction between potentia absoluta and potentia ordinata (Krötke 2001:205, 270), he maintains the point that this distinction wanted to safeguard, namely that God's power is not exhausted by the power God exercises in creating and recreating the world. For Krötke, God's creative power is 'greater' than his actual power in this world. It seems to me that there is a close connection between this greatness of God's power, its creative possibilities, and its empowering character. Because God's creative power is 'greater' than his power in this world, his power can be empowering. The creative character of God's empowering power suggests that we can understand God's creative power as a form of empowering power. This means that power is '(...) not a quality that God begrudges to others. On the contrary, the work of creation is precisely that by which God gives might to that which is not God (...)' (McFarland 2016:269-270).

God's creative power is empowering because it is the power of life. A central feature of God's power to create is his power to give life to other beings. Human beings cannot give life to themselves (Henriksen 2014:114). By contrast, God is the living God. He cannot be dead 'because that would mean that something other than this God was determining the life and death of "God," and hence the real God' (Henriksen 2014:119). The life of human beings and of other beings is a gift of the living God received by creatures. The act of creation is an act of giving. You cannot give something you do not possess yourself in one way or another. So, God can give life to other beings, because he himself is the living God. This suggests that God's power to create, his power to give life to other beings, is his own life.

We might infer from this that God's power is nothing else than his life, his radiant energy. Recently, Katherine Sonderegger has proposed this view. She argues that God's power is his life, his fiery energy that is radiating in this world. She not only identifies God's life and his power; her strong emphasis on God's oneness and unique divine simplicity leads her to the far-reaching and surprising claim that God himself is power. In her view, God does not have power; God is his own power, his own life, his own life. The God who is power, life and light is the source of all power, life and light in this world (Sonderegger 2015:188, 209-210, 325). God '(...) cannot but create, because He is Life; He cannot but radiate His Light and Blessing because $\mathrm{He}$ is Goodness itself (...)' (Sonderegger 2015:323). Although Sonderegger tries to understand this as a personal necessity (2015:317, 323), by identifying God's life with his creativity, the radiation of his clarities in the world becomes a kind of emanation, a necessary process (see Moltmann [1985] 1993:83-84). Thus, it becomes very difficult to understand created life as a gift. After all, a gift is only a gift if it is freely given and freely received. Because created life is a free gift, we cannot 'simply' identify God with his life and his life with his power. God is not power, he is powerful, he has power and he can freely choose to exercise his power or not. As Barth would put it: divine power remains God's own power.

But the claim that God's power to give life to other beings is his own life does not imply that divine life is homogeneous with created life. If divine life and created life are seen as homogeneous and their difference as a quantitative difference, God cannot give life to creatures without losing something of his own life. Then, a zero sum conception of divine and created life is inevitable. But created life and God's uncreated life are incommensurate (McFarland 2014:38), that is, qualitatively different. In the act of creation God does not give his own divine life to creatures; he gives them their own life, created life. Because God gives creatures their own, created life, qualitatively different from his own life, there can be no competition between his creative life and power and their created lives and powers. God's life and power does not limit their lives and powers, and their lives and powers do not limit God's life and power (cf. McFarland 2014:105-106).

Because God's creative power is his power to give life, it is quite the opposite of the power to dominate and oppress other human beings. Hobbes started his reflection on power from our 'natural condition', the war of all against all, and 
defined power as power against others. In this perspective, power is as such dominion and coercion. For Hobbes, this is also true of the power of God. In such a view, divine and human power can only be understood as opposed to each other, as the powers of enemies. If we start our reflection on God's power from the experience of our world and our life as a gift, we can understand God's creative power as the power to give life to others, power for others. In such a view, divine and human power can be seen as the powers of friends. Rowan Williams has rightly pointed out that, if we understand God's creative power this way, it makes no sense to see man as a victim of God's power and revolt as the only answer to the power of God (Williams [1989] 2000:68-69). God's creative power and the created power of human beings are not opposed, but cooperative. God and human beings are not doomed to be competitors; they can work together. The creative power of God, which is free and greater than his power in this world and also greater than wordly power, is the opposite of 'absolute power' in the modern sense, the arbitrary and violent power of a tyrant. God's power is not the power to take the life of human beings, as Hobbes told us, a story believed by many modern and postmodern thinkers; it is the power to give life to other beings and to make them flourish.

\section{Acknowledgements Competing interests}

The author declares that he has no financial or personal relationships which may have inappropriately influenced him in writing this article.

\section{References}

Aquino van, Th., 1265, Summa contra Gentiles.

Aquino van, Th., 1273, Summa theologiae.

Barth, K., 1942, Die Kirchliche Dogmatik II/1. Die Lehre von Gott, EVZ-Verlag, Zürich.

Barth, K, [1942] 1957, Church Dogmatics II.1. The Doctrine of God, T. \& T. Clark, Edinburgh.

Bauke-Ruegg, J., 1998, Die Almacht Gottes. Systematisch-theologische Erwägungen zwischen Metaphysik, Postmoderne und Poesie, Walter de Gruyter, Berlin.
Brink van den, G., 1993, Almighty God. A Study of the Doctrine of Divine Omnipotence, Kok, Kampen.

Cavanaugh, W.T., 2011, Migrations of the Holy. God, State, and the Political Meaning of the Church, Eerdmans, Grand Rapids, Mi.

Foisneau, L., 2000, Hobbes et la toute-puissance de Dieu, Presses Universitaires de France, Paris.

Foisneau, L., 2016, Hobbes, La vie inquiète, Gallimard, Paris.

Henriksen, J.-O., 2014, Life, Love \& Hope. God and Human Experience, Eerdmans Grand Rapids, Mi.

Hobbes, Th., 1651, Leviathan.

Jüngel, E., [1986] 1990, 'Gottes ursprüngliches Anfangen als schöpferische Selbstbegrenzung. Ein Beitrag zum Gespäch mit Hans Jonas über den "Gottesbegriff nach Auschwitz", in Wertlose Wahrheit. Zur Identität und Relevanz des christlichen Glaubens. Theologische Erörterungen III, Kaiser, München, 151-162.

Jüngel, E., [1999] 2003, 'Thesen zum Verhältnis von Existenz, Wesen und Eigenschaften Gottes', in Ganz werden. Theologische Erörterungen V, Mohr Siebeck, Tübingen, 253-273.

Kierkegaard, S., [1846] 2011, B.H. Kirmmse, K.B. Söderquist eds., Kierkegaards Journals and Notebooks 4, Princeton University Press, Princeton, 56-57 (= Pap. VII 1A 181).

Kooi van der, C., 2002, Als in een spiegel. God kennen volgens Calvijn en Barth, Kok, Kampen.

Krötke, W. 2001, Gottes Klarheiten. Eine Neuinterpretation der Lehre von Gottes 'Eigenschaften', Mohr Siebeck, Tübingen.

McFarland, I.A. 2014, From Nothing. A Theoolgy of Creation, Westminster John Knox Press, Louisville, Kentucky

McFarland, I.A. 2016, '“God the Father Almighty": A Theological Excursus', International Journal of Systematic Theology 18(3), 259-273.

Moltmann, J., [1985] 1993, God in Creation. A New Theology of Creation and the Spirit of God, Fortress, Minneapolis.

Moltmann, J., [1973] 2001, The Crucified God. The Cross of Christ as the Foundation and Criticism of Christian theology, SCM, London.

Moltmann, J., 2014, Der lebendige Gott und die Fülle des Lebens. Auch ein Beitrag zur gegenwärtigen Atheismusdebatte, Gütersloher Verlagshaus, Gütersloh.

Muis, J., 2016, Onze Vader. Christelijk spreken over God, Boekencentrum, Zoetermeer.

Osthövener, C.-D., 1996, Die Lehre von Gottes Eigenschaften bei Friedrich Schleiermacher und Karl Barth, Walter de Gruyter, Berlin.

Schleiermacher, F.D.E., [1821] 1960, Der christliche Glaube nach den Grundsätzen der evangelischen Kirche im Zusammenhange dargestellt I, M. Redeker ed., Walter de Gruyter, Berlin.

Shults, F.L., 2005, Reforming the Doctrine of God, Grand Rapids, Eerdmans, Grand Rapids, Mi.

Sonderegger, K., 2015, Systematic Theology I. The Doctrine of God, Fortress, Minneapolis.

Steinvorth, U., 2005, 'On Carl Schmitt's interpretation of Hobbes', in L. Foisneau e.a. ed., Leviathan between the Wars. Hobbes's Impact on Early Twentieth Century Political Philsophy, Peter Lang, Frankfurt am Main, 95-107.

Vos, P.H., 2002, De troost van het ogenblik. Kierkegaard over God en het lijden, Ten Have, Baarn.

Welker, M., 2013, God the Revealed. Christology, Eerdmans, Grand Rapids, Mi.

Williams, R., [1989] 2000, 'On Being Creatures', in On Christian Theology, Blackwell, Oxford, 63-79. 